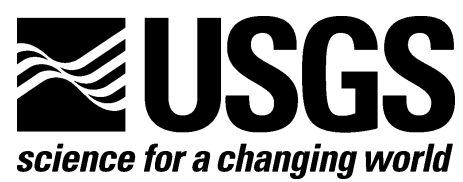

Prepared in cooperation with the State of Washington Military Department Emergency Management Division

\title{
Population and Business Exposure to Twenty Scenario Earthquakes in the State of Washington
}

Open-File Report 2011-1016

U.S. Department of the Interior

U.S. Geological Survey 



\section{Population and Business Exposure to Twenty Scenario Earthquakes in the State of Washington}

By Nathan Wood and Jamie Ratliff

Prepared in cooperation with the State of Washington Military Department Emergency Management Division

Open-File Report 2011-1016

U.S. Department of the Interior

U.S. Geological Survey 


\section{U.S. Department of the Interior \\ KEN SALAZAR, Secretary}

\section{U.S. Geological Survey \\ Marcia K. McNutt, Director}

U.S. Geological Survey, Reston, Virginia 2011

For product and ordering information:

World Wide Web: http://www.usgs.gov/pubprod

Telephone: 1-888-ASK-USGS

For more information on the USGS—-the Federal source for science about the Earth, its natural and living resources, natural hazards, and the environment:

World Wide Web: http://www.usgs.gov

Telephone: 1-888-ASK-USGS

Suggested citation:

Wood, N., and Ratliff, J., 2011, Population and business exposure to twenty scenario earthquakes in the State of Washington: U.S. Geological Survey Open-File Report 2011-1016, 13 p.

Any use of trade, product, or firm names is for descriptive purposes only and does not imply endorsement by the U.S. Government.

Although this report is in the public domain, permission must be secured from the individual copyright owners to reproduce any copyrighted material contained within this report. 


\section{Contents}

Introduction

Methods. 2

Results. 4

Acknowledgments. 13

References Cited 13

\section{Figures}

Figure 1. Study area map of scenario earthquakes in Washington (fault locations and extents generalized from U.S. Geological Survey, 2010, and Washington State Department of Natural Resources, 2010)......... 2

Figure 2. Residential population exposure to scenario earthquakes in Washington. ………………………..... 6

Figure 3. Exposure of occupied housing units to scenario earthquakes in Washington...................................... 7

Figure 4. Increase in residential population exposure to earthquakes, 1990 to 2000, in Washington.................. 9

Figure 5. Business exposure to scenario earthquakes in Washington............................................................ 10

Figure 6. Employee exposure to scenario earthquakes in Washington. .......................................................... 12

\section{Tables}

Table 1. Modified Mercalli Intensity (MMI) classes, including relations to peak-ground-acceleration values (Wald and others, 1999) and impact descriptions (abridged from U.S. Geological Survey, 1989)........ 3

Table 2. Residential population exposure to scenario earthquakes in Washington.......................................... 5

Table 3. Exposure of occupied housing units to scenario earthquakes in Washington....................................... 7

Table 4. Increase in residential population exposure to earthquakes, 1990 to 2000 , in Washington................... 8

Table 5. Business exposure to scenario earthquakes in Washington......................................................... 10

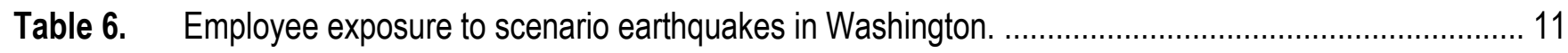




\title{
Population and Business Exposure to Twenty Scenario Earthquakes in the State of Washington
}

\author{
By Nathan Wood and Jamie Ratliff
}

\section{Introduction}

This report documents the results of an initial analysis of population and business exposure to scenario earthquakes in Washington. This analysis was conducted to support the U.S. Geological Survey (USGS) Pacific Northwest Multi-Hazards Demonstration Project (MHDP) and an ongoing collaboration between the State of Washington Emergency Management Division (WEMD) and the USGS on earthquake hazards and vulnerability topics. This report was developed to help WEMD meet internal planning needs. A subsequent report will provide analysis to the community level.

The objective of this project was to use scenario ground-motion hazard maps to estimate population and business exposure to twenty Washington earthquakes. In consultation with the USGS Earthquake Hazards Program and the Washington Division of Geology and Natural Resources, the twenty scenario earthquakes were selected by WEMD (fig. 1). Hazard maps were then produced by the USGS and placed in the USGS ShakeMap archive (U.S. Geological Survey, 2010). The scenario earthquakes and their moment magnitudes for this study are:

Boulder Creek Fault $M$ 6.8;

Canyon River-Price Lake Fault $M 7.4$;

Cascadia subduction zone megathrust $M 9.0$;

Cascadia subduction zone megathrust (northern section) $M$ 8.3;

Chelan Fault $M$ 7.2;

Cle Elum-Wallula deformed zone $M$ 6.8;

Devils Mountain Fault $M 7.1$;

Devils Mountain Fault (western section) $M 7.4$;

Hite Fault $M$ 6.8;

Little River Fault (Lake Creek) $M$ 6.8;

Toppenish Ridge Fault (Mill Creek) M 7.1;

Mount Saint Helens deformed zone $M 7.0$;

Nisqually intraslab zone $M 7.2$;

Saddle Mountain Fault $M 7.35$;

Sea-Tac intraslab zone $M 7.2$;

Seattle Fault $M$ 7.2;

Spokane blind fault $M$ 5.5;

Southern Whidbey Island Fault (SWIF) zone M 7.4;

Southern Whidbey Island Fault (SWIF) zone (southeastern section) $M 7.2$; and

Tacoma Fault M 7.1. 


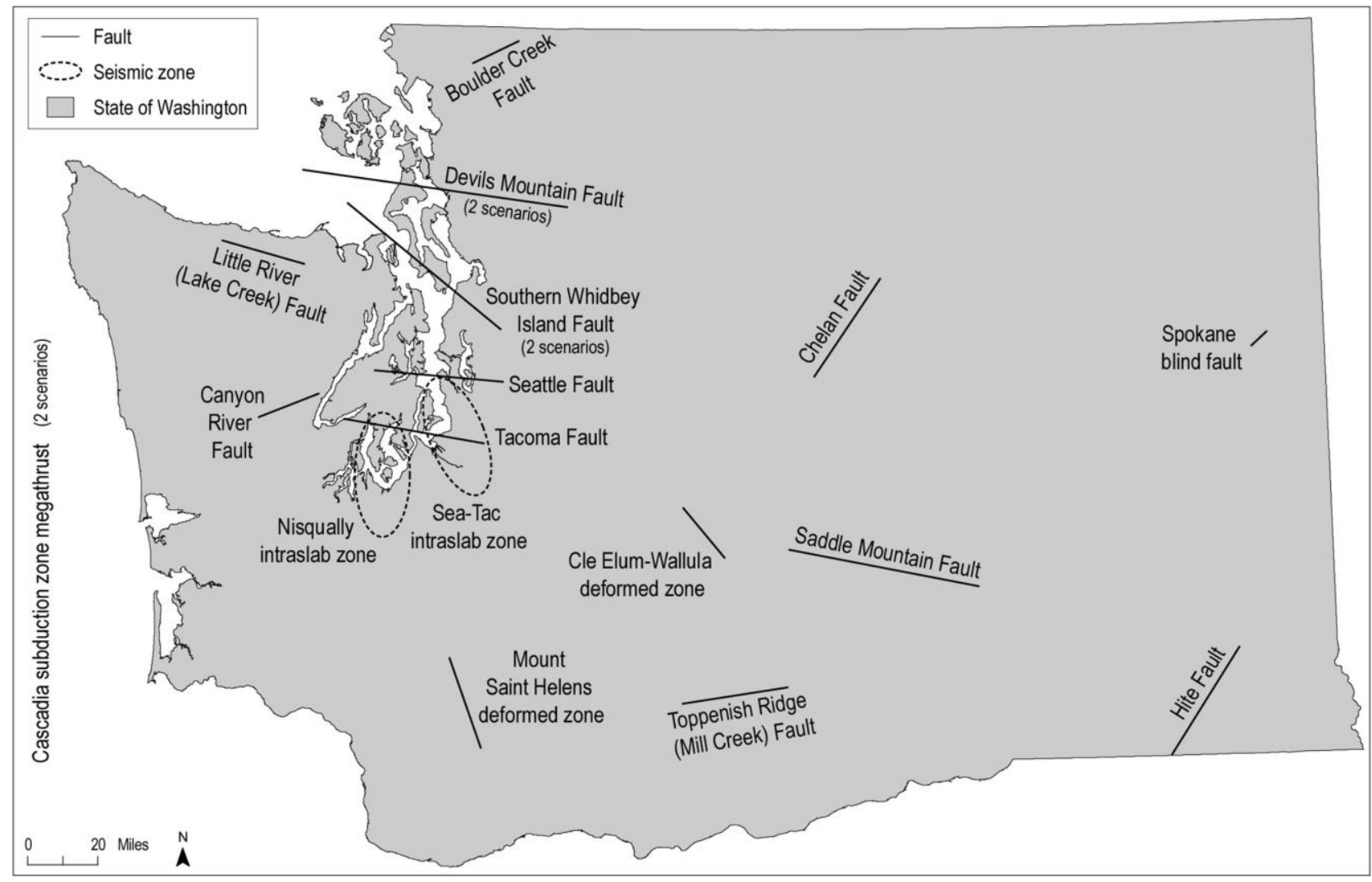

Figure 1. Study area map of scenario earthquakes in Washington (fault locations and extents generalized from U.S. Geological Survey, 2010, and Washington State Department of Natural Resources, 2010).

\section{Methods}

To describe population and business exposure to scenario earthquakes, geographic-informationsystem (GIS) tools were used to integrate publicly available hazard and socioeconomic data.

Earthquake-hazard zones were delineated using GIS polygons that represent peak-ground-acceleration (PGA) values from the USGS ShakeMap archive (U.S. Geological Survey, 2010). PGA values were translated and represented by Modified Mercalli Intensity (MMI) classes. MMI describes the severity of an earthquake in terms of its effect on humans and structures. We used MMI classes instead of PGA values at WEMD's request because MMI classes are more easily understood by emergency managers than PGA values. Table 1 summarizes the relation between PGA values and MMI classes, as well as providing a description of societal impacts at each MMI level. 
Table 1. Modified Mercalli Intensity (MMI) classes, including relations to peak-ground-acceleration values (Wald and others, 1999) and impact descriptions (abridged from U.S. Geological Survey, 1989).

\begin{tabular}{|c|c|c|}
\hline $\begin{array}{l}\text { Modified Mercalli } \\
\text { Intensity }\end{array}$ & $\begin{array}{c}\text { Peak Ground } \\
\text { Acceleration (PGA) }\end{array}$ & Description of Societal Impact \\
\hline I & $<0.0017 g$ & Not felt except by a very few under especially favorable conditions \\
\hline II & $0.0017-0.014 g$ & $\begin{array}{l}\text { Felt only by a few persons at rest, especially on upper floors of } \\
\text { buildings }\end{array}$ \\
\hline III & $0.0017-0.014 g$ & $\begin{array}{l}\text { Felt quite noticeably by persons indoors, especially on upper floors of } \\
\text { buildings. Many people do not recognize it as an earthquake. Standing } \\
\text { motor cars may rock slightly. Vibrations similar to the passing of a } \\
\text { truck. Duration estimated. }\end{array}$ \\
\hline IV & $0.014-0.039 g$ & $\begin{array}{l}\text { Felt indoors by many, outdoors by few during the day. At night, some } \\
\text { awakened. Dishes, windows, doors disturbed; walls make cracking } \\
\text { sound. Sensation like heavy truck striking building. Standing motor cars } \\
\text { rocked noticeably }\end{array}$ \\
\hline $\mathrm{V}$ & $0.039-0.092 g$ & $\begin{array}{l}\text { Felt by nearly everyone; many awakened. Some dishes, windows } \\
\text { broken. Unstable objects overturned. Pendulum clocks may stop }\end{array}$ \\
\hline VI & $0.092-0.18 g$ & $\begin{array}{l}\text { Felt by all, many frightened. Some heavy furniture moved; a few } \\
\text { instances of fallen plaster. Damage slight }\end{array}$ \\
\hline VII & $0.18-0.34 g$ & $\begin{array}{l}\text { Damage negligible in buildings of good design and construction; slight } \\
\text { to moderate in well-built ordinary structures; considerable damage in } \\
\text { poorly built or badly designed structures; some chimneys broken. }\end{array}$ \\
\hline VIII & $0.34-0.65 g$ & $\begin{array}{l}\text { Damage slight in specially designed structures; considerable damage in } \\
\text { ordinary substantial buildings with partial collapse. Damage great in } \\
\text { poorly built structures. Fall of chimneys, factory stacks, columns, } \\
\text { monuments, walls. Heavy furniture overturned }\end{array}$ \\
\hline IX & $0.65-1.24 g$ & $\begin{array}{l}\text { Damage considerable in specially designed structures; well-designed } \\
\text { frame structures thrown out of plumb. Damage great in substantial } \\
\text { buildings, with partial collapse. Buildings shifted off foundations }\end{array}$ \\
\hline $\mathrm{X}$ & $>1.24 \mathrm{~g}$ & $\begin{array}{l}\text { Some well-built wooden structures destroyed; most masonry and frame } \\
\text { structures destroyed with foundations. Rails bent. }\end{array}$ \\
\hline
\end{tabular}


Societal-asset calculations focus on the number of residents and businesses in the various earthquake-hazard zones. These assets are determined because U.S. jurisdictions are encouraged to collect similar data as they develop State and local mitigation plans (Federal Emergency Management Agency, 2001), a requirement to qualify for funds under the U.S. Hazard Mitigation Grant Program in accordance with the Disaster Mitigation Act of 2000, Public Law 106-390. Data used in this analysis include:

Population - based on block-level population counts (GIS polygons) compiled for the 1990 and 2000 U.S. Census (U.S. Census Bureau, 2009) that identifies total residents and occupied housing units; and

Business — based on the 2010 infoUSA Employer Database, a proprietary business database (GIS point file) that identifies location of businesses, number of employees, total sales volume, and the North American Industry Classification System (NAICS) code (infoUSA, 2010).

Before analysis, geospatial data were transformed to share the same datum (North American Datum of 1983, High Accuracy Reference Network, State Plane, Washington, South, FIPS 4602 Feet) and projection (Lambert Conformal Conic), thereby conforming to existing GIS data from the State of Washington's GIS database. Spatial analysis of vector data (for example, population polygons and business points) focused on determining whether or not points and polygons are inside earthquakehazard zones. Slivers of population polygons that overlap earthquake-hazard zones were taken into account during analysis, and final values were adjusted proportionately.

In the tables and stacked bar-graphs, we have chosen to summarize resident, employee, housing unit, and business counts only for MMI V and above. In discussion with WEMD staff, we agreed that peak-ground-acceleration values at MMI V represent the beginning of significant earthquake-related impacts and damages. Calculations at lower MMI levels are likely to be less useful to emergency managers and therefore were not performed.

The results summarized in this report should be considered first approximations of population and business exposure and not exhaustive inventories. The ShakeMap geospatial layers we received had explicit spatial boundaries. Therefore, certain MMI zones, especially lower classes (MMI V for many scenarios, as well as MMI VI for the SWIF southeastern scenario), were clipped at study-area boundaries and do not represent the entire area likely to experience a certain level of ground shaking. Finally, this assessment of population and business exposure to earthquake hazards is based on scenario earthquakes and ground-shaking models. The results are not definitive loss estimates and are designed solely to help local and State emergency managers in their earthquake preparedness and planning efforts.

\section{Results}

Data presented in this initial report were generated to provide information for the WEMD staff. A subsequent report will build on this initial analysis with results tailored to individual communities and counties that could be impacted by the various scenario earthquakes. Preliminary results are presented in both tables and graphs to satisfy various needs of emergency managers. Results reported here include the number of residents, occupied housing units, businesses, and employees in the areas affected by the various MMI classes related to the twenty earthquake scenarios. We also calculate the change in residential exposure to earthquake hazards between 1990 and 2000. 
On the basis of the 2000 Census, there are millions of Washington residents living in areas prone to significant ground shaking (table 2; fig. 2). The earthquake scenario with the highest number of residents in earthquake-hazard zones (MMI V and greater) is a Cascadia subduction zone (CSZ) megathrust earthquake. More than 5 million people are living in zones prone to MMI V and above ground shaking for earthquakes along the entire CSZ (M 9.0) and also for just the northern section of the CSZ (M 8.0).

Although CSZ earthquakes represent the highest overall residential exposure in Washington, a $M$ 7.4 earthquake within the Southern Whidbey Island Fault (SWIF) zone could expose the highest number of residents (more than 137,000) to the greatest ground shaking (MMI IX) projected for the State. A $M$ 7.1 earthquake on the Tacoma Fault could also expose a significant number of residents (approximately 62,000) to MMI IX ground shaking. Earthquake scenarios for the CSZ are not projected to expose any populations in the State of Washington to MMI IX ground shaking.

Table 2. Residential population exposure to scenario earthquakes in Washington.

\begin{tabular}{|c|c|c|c|c|c|c|}
\hline \multirow{2}{*}{ Earthquake scenario } & \multicolumn{6}{|c|}{ Exposed residential population in 2000 , organized by MMI class } \\
\hline & V & VI & VII & VIII & IX & TOTALS \\
\hline Boulder Creek $M 6.8$ & 528,183 & 136,908 & 13,857 & 3,463 & 321 & 682,732 \\
\hline Canyon River $M 7.4$ & $2,901,320$ & 791,490 & 39,459 & 2,861 & 116 & $3,735,245$ \\
\hline Cascadia $M 9.0$ & 780,400 & 989,190 & $3,482,525$ & 109,738 & 0 & $5,361,853$ \\
\hline Cascadia (northern section) $M 8.3$ & $3,415,432$ & $1,674,719$ & 207,926 & 8,901 & 0 & $5,306,978$ \\
\hline Chelan $M 7.2$ & 124,342 & 49,019 & 71,190 & 10,078 & 167 & 254,796 \\
\hline Cle Elum $M 6.8$ & $1,575,609$ & 149,362 & 38,234 & 401 & 17 & $1,763,623$ \\
\hline Devils Mountain $M 7.1$ & $2,394,711$ & 397,411 & 107,617 & 45,873 & 2,164 & $2,947,777$ \\
\hline Devils Mountain (western section) $M 7.4$ & $2,161,370$ & 572,988 & 118,136 & 98,997 & 720 & $2,952,211$ \\
\hline Hite $M 6.8$ & 139,232 & 3,235 & 23,537 & 29,266 & 0 & 195,269 \\
\hline Lake Creek $M 6.8$ & $3,682,057$ & 16,370 & 18,110 & 32,770 & 1,726 & $3,751,033$ \\
\hline Mill Creek M 7.1 & 322,549 & 157,650 & 69,938 & 3,147 & 20 & 553,304 \\
\hline Mt St Helens Zone $M 7.0$ & $1,284,015$ & 100,031 & 5,532 & 1,203 & 0 & $1,390,781$ \\
\hline Nisqually $M 7.2$ & 47,061 & $1,448,439$ & $2,262,156$ & 0 & 0 & $3,757,656$ \\
\hline Saddle Mountain $M 7.35$ & 197,958 & 426,628 & 47,245 & 13,363 & 255 & 685,449 \\
\hline SeaTac $M 7.2$ & 52,207 & 445,927 & $3,305,549$ & 0 & 0 & $3,803,683$ \\
\hline Seattle $M 7.2$ & 355,105 & $1,441,297$ & $1,103,800$ & $1,035,911$ & 0 & $3,936,113$ \\
\hline Spokane $M 5.5$ & 126,124 & 136,667 & 181,365 & 0 & 0 & 444,156 \\
\hline SWIF $M 7.4$ & $1,270,495$ & $1,221,859$ & $1,070,349$ & 403,838 & 137,848 & $4,104,389$ \\
\hline SWIF (southeastern section) $M 7.2$ & $1,203,827$ & $1,576,691$ & 906,266 & 249,304 & 0 & $3,936,088$ \\
\hline Tacoma $M 7.1$ & 799,104 & $1,477,240$ & $1,097,000$ & 406,773 & 61,915 & $3,842,031$ \\
\hline
\end{tabular}




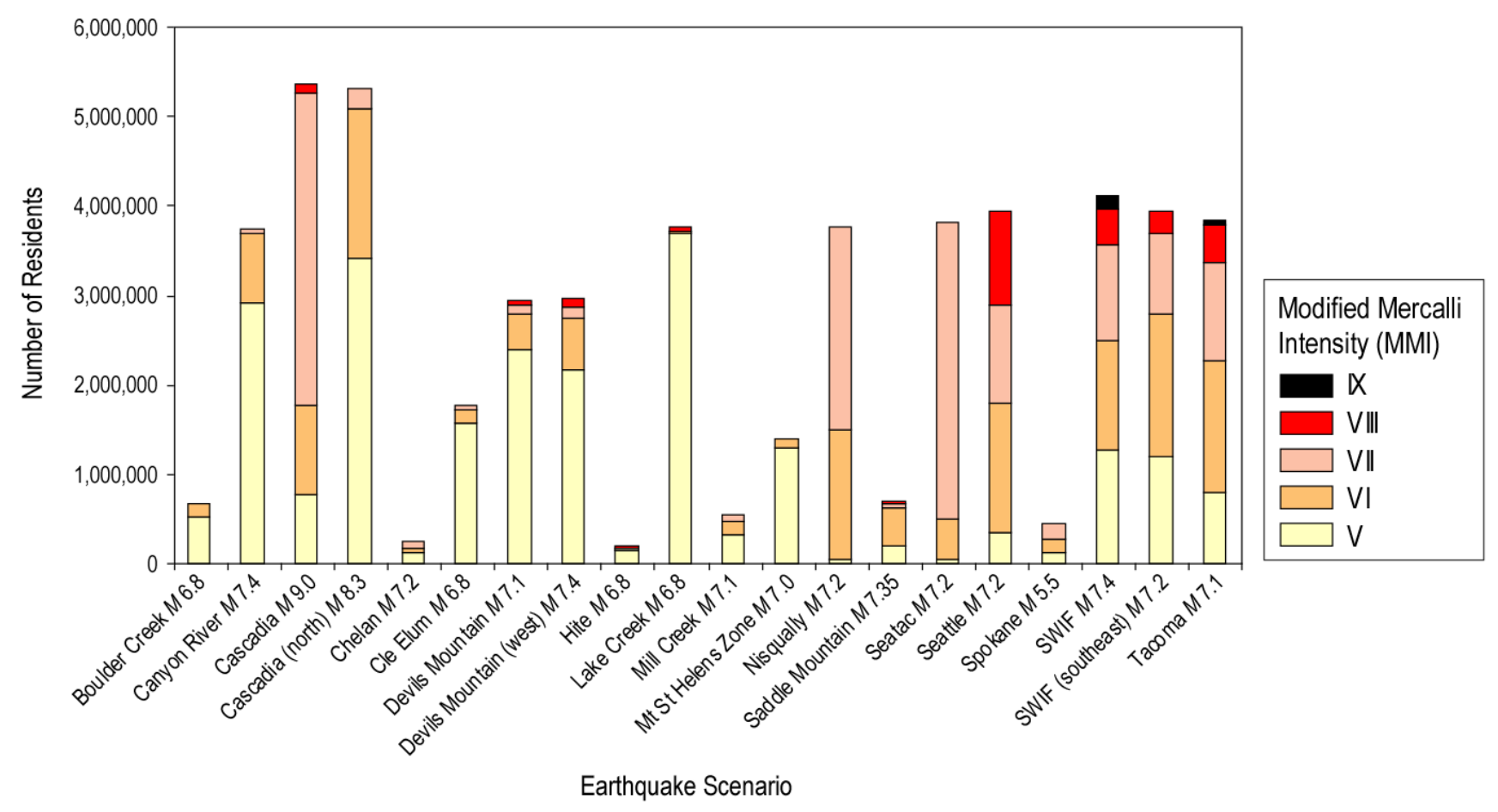

Figure 2. Residential population exposure to scenario earthquakes in Washington.

The exposure of occupied housing units, not surprisingly, follows the trends in residential exposure (table 3; fig. 3). Exposure of occupied housing units to MMI V to IX ground-shaking classes ranges from approximately 68,000 for a $M 6.8$ Hite Fault earthquake to more than 2 million for a CSZ earthquake. Earthquakes related to the SWIF (M 7.4) and the Tacoma Fault (M 7.1) would expose the greatest number of occupied housing units to the greatest ground-shaking potential (more than 51,000 and 23,000 housing units, respectively, to MMI IX shaking). 
Table 3. Exposure of occupied housing units to scenario earthquakes in Washington.

\begin{tabular}{lllllll}
\hline \multirow{2}{*}{ Earthquake scenario } & \multicolumn{4}{c}{ Exposed occupied housing units in 2000, organized by MMI class } \\
& \multicolumn{1}{c}{ V } & \multicolumn{1}{c}{ VI } & \multicolumn{1}{c}{ VII } & \multicolumn{1}{c}{ VIII } & IX & \multicolumn{1}{c}{ TOTALS } \\
\hline Boulder Creek $M$ 6.8 & 203,804 & 52,679 & 4,671 & 1,179 & 118 & 262,451 \\
Canyon River $M$ 7.4 & $1,135,578$ & 318,863 & 14,552 & 1,357 & 58 & $1,470,408$ \\
Cascadia $M$ 9.0 & 275,627 & 361,110 & $1,384,118$ & 43,002 & 0 & $2,063,857$ \\
Cascadia (northern section) $M$ 8.3 & $1,328,325$ & 628,800 & 81,135 & 4,161 & 0 & $2,042,421$ \\
Chelan $M$ 7.2 & 45,657 & 18,038 & 26,224 & 3,593 & 72 & 93,585 \\
Cle Elum $M$ 6.8 & 586,065 & 53,299 & 14,721 & 152 & 8 & 654,246 \\
Devils Mountain $M$ 7.1 & 965,101 & 151,125 & 39,312 & 16,634 & 829 & $1,173,001$ \\
Devils Mountain (western section) $M 7.4$ & 872,284 & 220,586 & 44,277 & 37,108 & 312 & $1,174,567$ \\
Hite $M$ 6.8 & 47,909 & 1,063 & 9,022 & 10,202 & 0 & 68,195 \\
Lake Creek $M$ 6.8 & $1,447,013$ & 7,254 & 8,365 & 13,965 & 661 & $1,477,258$ \\
Mill Creek $M$ 7.1 & 114,445 & 56,711 & 19,425 & 796 & 5 & 191,383 \\
Mt St Helens Zone $M 7.0$ & 478,782 & 37,980 & 2,184 & 493 & 0 & 519,439 \\
Nisqually $M$ 7.2 & 17,926 & 565,224 & 893,998 & 0 & 0 & $1,477,148$ \\
Saddle Mountain $M$ 7.35 & 72,425 & 146,633 & 16,426 & 3,469 & 75 & 239,028 \\
SeaTac $M$ 7.2 & 21,147 & 170,133 & $1,301,711$ & 0 & 0 & $1,492,991$ \\
Seattle $M$ 7.2 & 138,222 & 542,087 & 432,342 & 431,866 & 0 & $1,544,516$ \\
Spokane $M$ 5.5 & 44,778 & 52,120 & 76,451 & 0 & 0 & 173,349 \\
SWIF $M$ 7.4 & 479,709 & 479,095 & 448,132 & 151,450 & 51,672 & $1,610,059$ \\
SWIF (southeastern section) $M$ 7.2 & 455,320 & 632,095 & 358,475 & 98,615 & 0 & $1,544,506$ \\
Tacoma $M$ 7.1 & 305,286 & 592,176 & 432,761 & 154,974 & 23,696 & $1,508,892$ \\
\hline
\end{tabular}

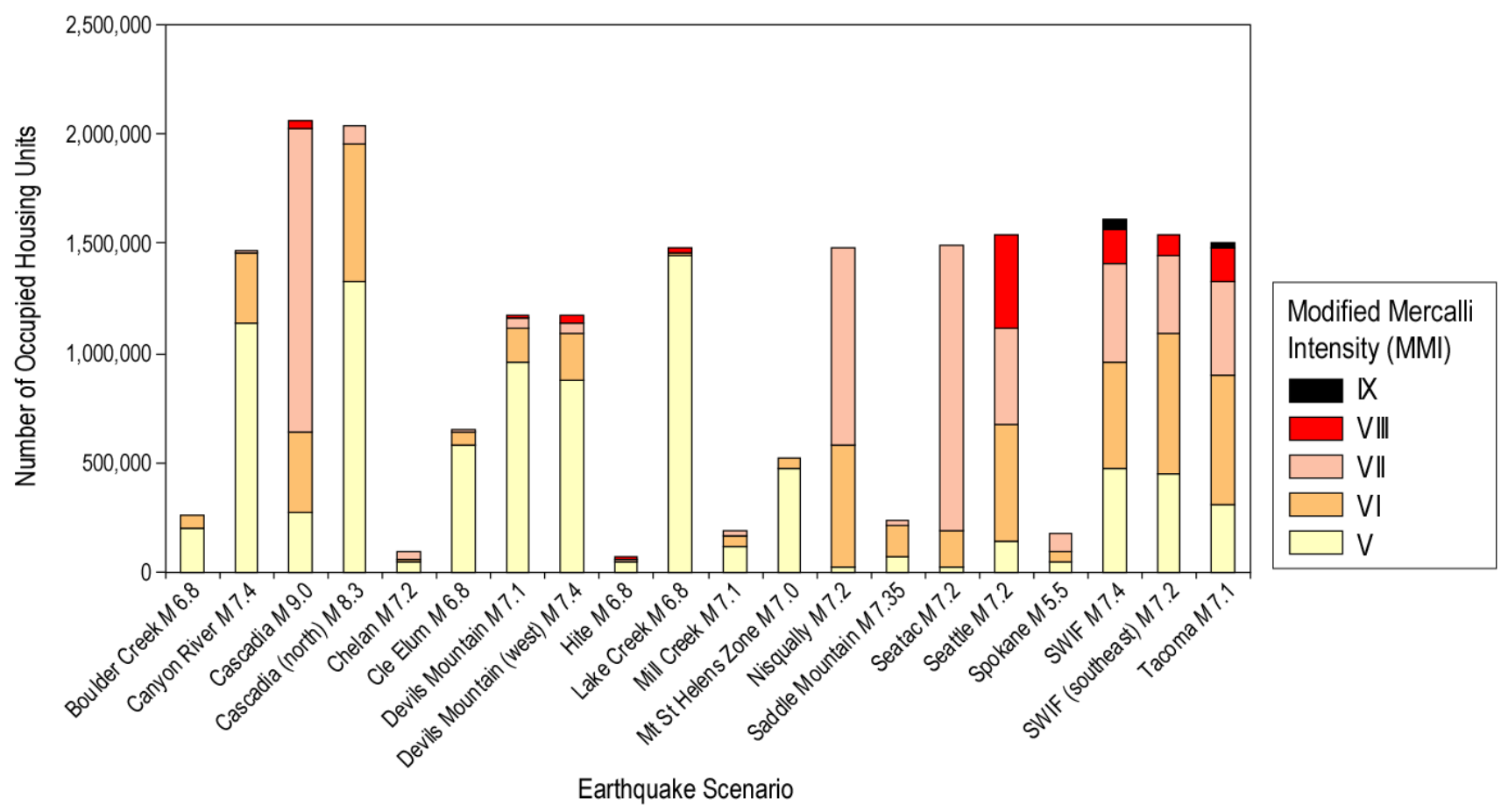

Figure 3. Exposure of occupied housing units to scenario earthquakes in Washington. 
Between 1990 and 2000, the exposure of residential populations has increased across the State of Washington (table 4; fig. 4). The greatest increases were related to CSZ earthquakes. Although residential exposure has increased between 1990 and 2000, a comparison of figures 2 and 4 suggests that increases in residential exposure are not unique to any one earthquake scenario and that population across the State of Washington increased fairly uniformly.

Table 4. Increase in residential population exposure to earthquakes, 1990 to 2000, in Washington.

\begin{tabular}{|c|c|c|c|c|c|c|}
\hline \multirow{2}{*}{ Earthquake scenario } & \multicolumn{6}{|c|}{ Increase in residential exposure to earthquakes, 1990 to 2000 , by MMI class } \\
\hline & V & VI & VII & VIII & IX & TOTALS \\
\hline Boulder Creek $M 6.8$ & 119,702 & 31,139 & 2,071 & 2,243 & 119 & 155,274 \\
\hline Canyon River $M 7.4$ & 458,958 & 124,235 & 8,319 & 595 & 65 & 592,173 \\
\hline Cascadia $M 9.0$ & 145,145 & 272,080 & 528,423 & 9,021 & 0 & 954,668 \\
\hline Cascadia (northern section) $M 8.3$ & 576,409 & 348,586 & 21,282 & 1,352 & 0 & 947,629 \\
\hline Chelan $M 7.2$ & 25,259 & 10,951 & 14,056 & 1,679 & 36 & 51,981 \\
\hline Cle Elum $M 6.8$ & 301,478 & 23,447 & 6,989 & 35 & 4 & 331,953 \\
\hline Devils Mountain $M 7.1$ & 357,674 & 95,674 & 24,896 & 11,774 & 638 & 490,657 \\
\hline Devils Mountain (western section) $M 7.4$ & 295,434 & 146,687 & 30,720 & 16,981 & 56 & 489,878 \\
\hline Hite $M 6.8$ & 25,220 & 1,031 & 2,481 & 2,580 & 0 & 31,311 \\
\hline Lake Creek $M 6.8$ & 596,939 & 4,032 & 3,943 & 2,721 & 512 & 608,147 \\
\hline Mill Creek M 7.1 & 72,297 & 24,200 & 10,103 & 318 & 12 & 106,929 \\
\hline Mt St Helens Zone $M 7.0$ & 265,128 & 15,290 & 640 & 78 & 0 & 281,136 \\
\hline Nisqually $M 7.2$ & 6,443 & 243,153 & 349,527 & 0 & 0 & 599,123 \\
\hline Saddle Mountain $M 7.35$ & 34,798 & 80,269 & 9,688 & 5,342 & 74 & 130,172 \\
\hline SeaTac $M 7.2$ & 4,166 & 99,380 & 519,388 & 0 & 0 & 622,934 \\
\hline Seattle $M 7.2$ & 59,233 & 293,715 & 163,643 & 130,761 & 0 & 647,351 \\
\hline Spokane $M 5.5$ & 27,416 & 26,080 & 10,072 & 0 & 0 & 63,568 \\
\hline SWIF $M 7.4$ & 237,609 & 183,914 & 151,993 & 76,315 & 40,101 & 689,933 \\
\hline SWIF (southeastern section) $M 7.2$ & 204,025 & 243,189 & 144,804 & 55,332 & 0 & 647,350 \\
\hline Tacoma $M 7.1$ & 173,728 & 217,415 & 149,156 & 75,034 & 8,795 & 624,128 \\
\hline
\end{tabular}




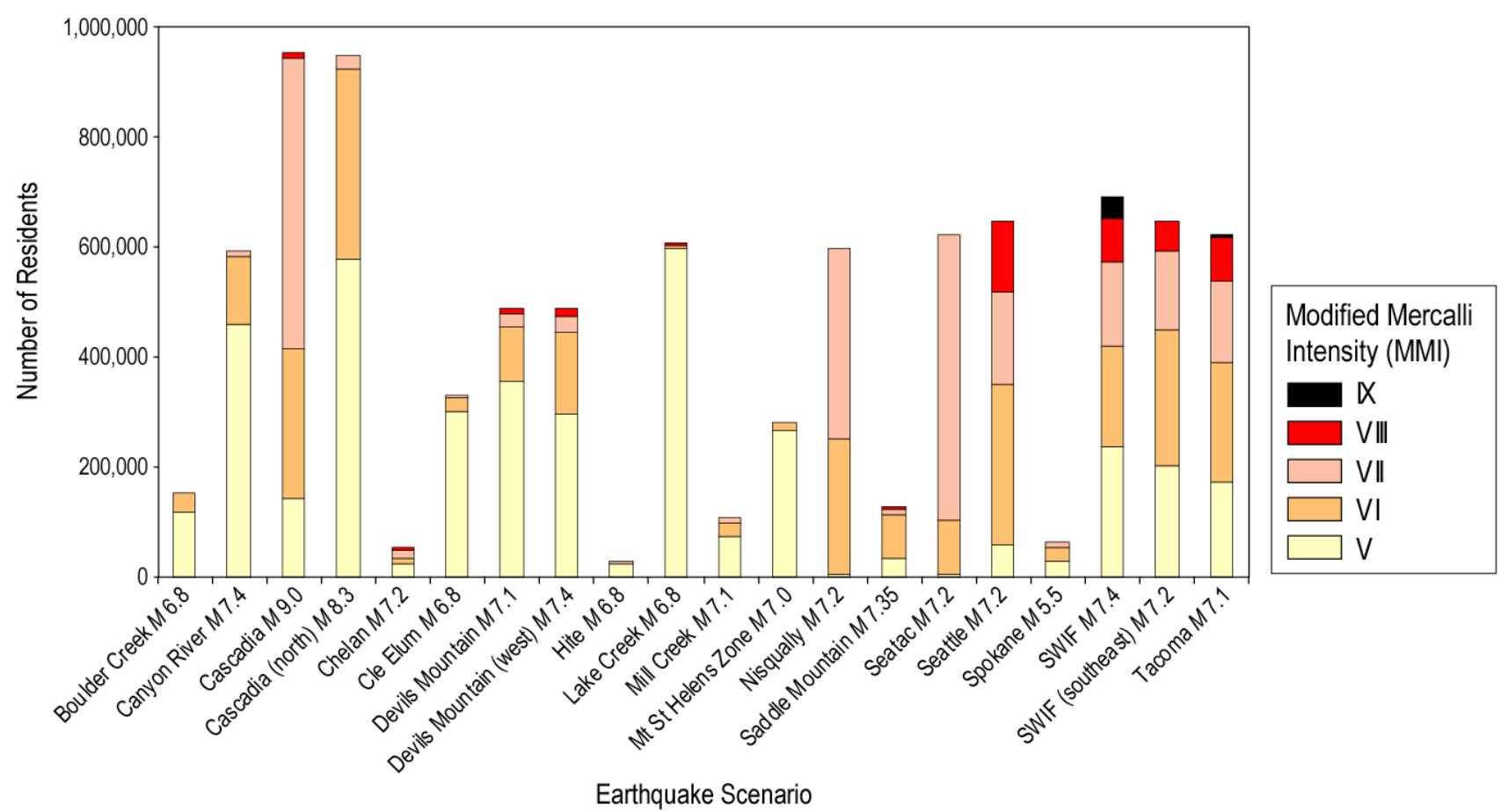

Figure 4. Increase in residential population exposure to earthquakes, 1990 to 2000, in Washington.

The exposure of businesses to MMI V to IX ground-shaking classes ranges from approximately 6,500 for a $M$ 6.8 Hite Fault earthquake to more than 200,000 for a CSZ earthquake (table 5; fig. 5). This analysis of business exposure does not differentiate between small businesses with only a few employees and large corporations with thousands of employees. A subsequent analysis of employee exposure accounts for variations in business size.

An earthquake related to the Seattle Fault (M 7.2) would likely have the greatest impact to business communities, as it could expose more than 55,000 businesses to MMI VIII ground shaking. Earthquake scenarios for the SWIF (M 7.4) and Tacoma Fault (M 7.1) would expose several thousands of businesses to MMI IX ground shaking (3,827 and 1,486, respectively) but would have significantly lower numbers of businesses in MMI VIII classes (14,339 and 14,950 businesses, respectively) than a Seattle $M 7.2$ earthquake scenario. In general, scenario earthquakes associated with the Seattle, SWIF, and Tacoma faults likely represent the greatest threats to businesses of the twenty scenarios in this study. 
Table 5. Business exposure to scenario earthquakes in Washington.

\begin{tabular}{lllllll}
\hline \multicolumn{1}{c}{ Earthquake scenario } & \multicolumn{5}{c}{ Exposed businesses in 2010, organized by MMI class } \\
& \multicolumn{1}{c}{ V } & \multicolumn{1}{c}{ VI } & \multicolumn{1}{c}{ VII } & VIII & IX & TOTALS \\
\hline Boulder Creek $M$ 6.8 & 20,529 & 6,507 & 341 & 50 & 8 & 27,435 \\
Canyon River $M$ 7.4 & 105,931 & 44,614 & 1,275 & 47 & 1 & 151,868 \\
Cascadia $M$ 9.0 & 26,841 & 33,629 & 146,947 & 3,467 & 0 & 210,884 \\
Cascadia (northern section) $M$ 8.3 & 142,043 & 59,683 & 7,587 & 199 & 0 & 209,512 \\
Chelan $M$ 7.2 & 4,529 & 1,692 & 3,077 & 168 & 1 & 9,467 \\
Cle Elum $M$ 6.8 & 57,498 & 5,633 & 1,776 & 14 & 0 & 64,921 \\
Devils Mountain $M$ 7.1 & 104,685 & 15,583 & 3,624 & 2,321 & 49 & 126,262 \\
Devils Mountain (western section) $M$ 7.4 & 95,457 & 22,350 & 4,264 & 4,226 & 27 & 126,324 \\
Hite $M$ 6.8 & 4,268 & 70 & 779 & 1,450 & 0 & 6,567 \\
Lake Creek $M$ 6.8 & 152,171 & 1,130 & 1,100 & 1,759 & 30 & 156,190 \\
Mill Creek $M$ 7.1 & 11,531 & 6,199 & 1,414 & 43 & 0 & 19,187 \\
Mt St Helens Zone $M$ 7.0 & 44,323 & 4,129 & 99 & 8 & 0 & 48,559 \\
Nisqually $M$ 7.2 & 880 & 51,918 & 98,587 & 0 & 0 & 151,385 \\
Saddle Mountain $M$ 7.35 & 6,948 & 15,710 & 1,830 & 223 & 5 & 24,716 \\
SeaTac $M$ 7.2 & 1,631 & 15,657 & 136,628 & 0 & 0 & 153,916 \\
Seattle $M$ 7.2 & 12,531 & 51,830 & 39,569 & 55,907 & 0 & 159,837 \\
Spokane $M$ 5.5 & 3,620 & 5,137 & 9,516 & 0 & 0 & 18,273 \\
SWIF $M$ 7.4 & 43,698 & 53,917 & 52,249 & 14,339 & 3,827 & 168,030 \\
SWIF (southeastern section) $M$ 7.2 & 42,863 & 73,945 & 34,264 & 8,765 & 0 & 159,837 \\
Tacoma $M$ 7.1 & 26,797 & 61,129 & 50,819 & 14,950 & 1,486 & 155,181 \\
\hline
\end{tabular}

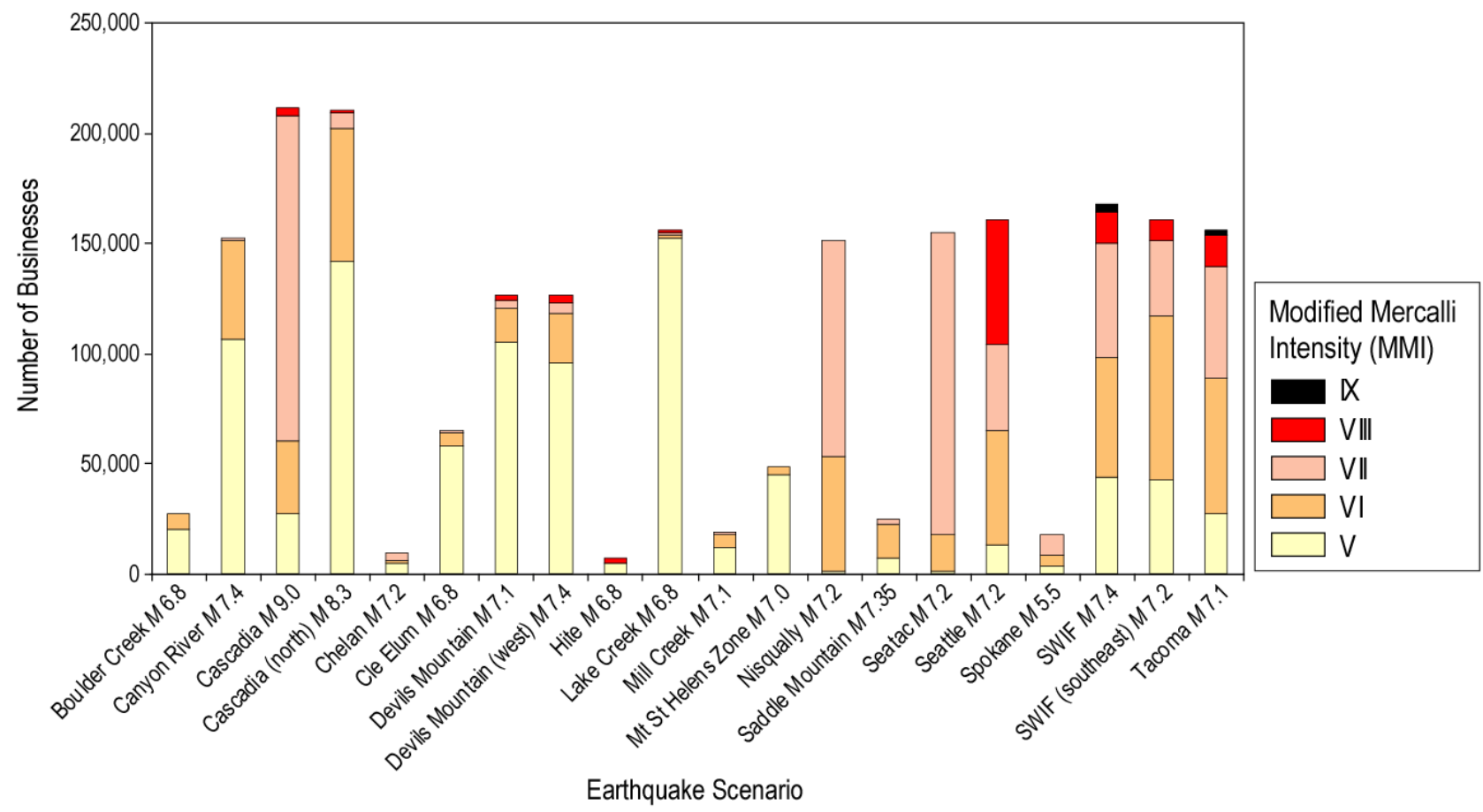

Figure 5. Business exposure to scenario earthquakes in Washington. 
The exposure of employees to MMI V to IX ground-shaking classes ranges from approximately 68,000 for a $M 6.8$ Hite Fault earthquake to more than 2.2 million for a CSZ earthquake (table 6; fig. 6). An earthquake related to the Seattle Fault (M 7.2) would likely have the greatest impact to business communities, as it could expose more than 678,000 employees to MMI VIII ground shaking. Again, earthquake scenarios for the SWIF (M 7.4) and Tacoma Fault (M 7.1) would expose significant numbers of employees to MMI IX ground shaking (42,737 and 9,567, respectively) but would have significantly lower numbers than a Seattle scenario in MMI VIII classes (both approximately one-third of Seattle Fault estimates).

Table 6. Employee exposure to scenario earthquakes in Washington.

\begin{tabular}{lllllll}
\hline \multicolumn{1}{c}{ Earthquake scenario } & \multicolumn{5}{c}{ Number of Employees (2010), organized by MMI class } \\
& \multicolumn{1}{c}{ V } & \multicolumn{1}{c}{ VI } & \multicolumn{1}{c}{ VII } & VIII & IX & TOTALS \\
\hline Boulder Creek $M$ 6.8 & 188,657 & 66,923 & 2,564 & 202 & 18 & 258,364 \\
Canyon River $M$ 7.4 & $1,112,577$ & 575,656 & 9,616 & 253 & 30 & $1,698,132$ \\
Cascadia $M$ 9.0 & 291,546 & 297,972 & $1,662,116$ & 27,755 & 0 & $2,279,389$ \\
Cascadia (northern section) $M 8.3$ & $1,549,172$ & 651,810 & 68,419 & 789 & 0 & $2,270,190$ \\
Chelan $M$ 7.2 & 46,788 & 13,648 & 33,358 & 1,674 & 1 & 95,469 \\
Cle Elum $M$ 6.8 & 657,580 & 62,266 & 11,567 & 52 & 0 & 731,465 \\
Devils Mountain $M$ 7.1 & $1,161,231$ & 153,138 & 34,050 & 22,547 & 233 & $1,371,199$ \\
Devils Mountain (western section) $M 7.4$ & $1,077,903$ & 221,021 & 36,928 & 36,942 & 70 & $1,372,864$ \\
Hite $M$ 6.8 & 46,683 & 2,386 & 5,314 & 13,839 & 0 & 68,222 \\
Lake Creek $M$ 6.8 & $1,717,686$ & 6,729 & 6,018 & 15,114 & 136 & $1,745,683$ \\
Mill Creek $M$ 7.1 & 134,814 & 66,648 & 18,388 & 659 & 0 & 220,509 \\
Mt St Helens Zone $M$ 7.0 & 460,550 & 38,141 & 512 & 73 & 0 & 499,276 \\
Nisqually $M$ 7.2 & 4,369 & 531,130 & $1,155,059$ & 0 & 0 & $1,690,558$ \\
Saddle Mountain $M$ 7.35 & 64,699 & 195,056 & 15,340 & 2,499 & 47 & 277,641 \\
SeaTac $M$ 7.2 & 14,375 & 132,619 & $1,562,848$ & 0 & 0 & $1,709,842$ \\
Seattle $M$ 7.2 & 101,488 & 564,679 & 417,017 & 678,087 & 0 & $1,761,271$ \\
Spokane $M$ 5.5 & 35,044 & 50,967 & 124,568 & 0 & 0 & 210,579 \\
SWIF $M$ 7.4 & 448,337 & 628,400 & 574,810 & 143,361 & 42,737 & $1,837,645$ \\
SWIF (southeastern section) $M 7.2$ & 464,566 & 877,856 & 333,159 & 85,690 & 0 & $1,761,271$ \\
Tacoma $M$ 7.1 & 245,299 & 655,844 & 618,869 & 191,380 & 9,567 & $1,720,959$ \\
\hline
\end{tabular}




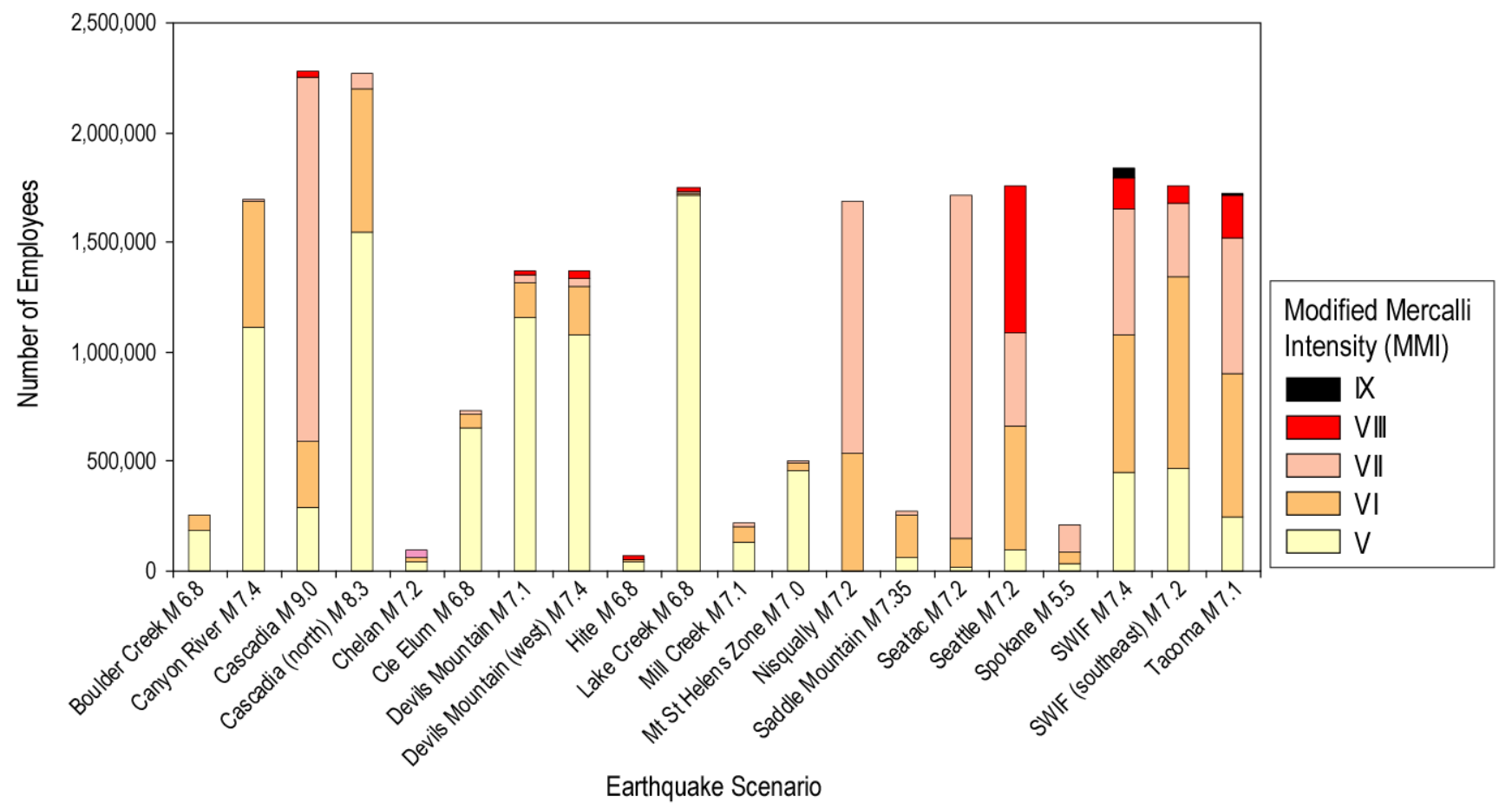

Figure 6. Employee exposure to scenario earthquakes in Washington. 


\section{Acknowledgments}

This report was supported by funds from the USGS Earthquake Hazards Program (EHP) and the USGS Geographic Analysis and Monitoring Program. We thank John Schelling of the State of Washington Emergency Management Division (WEMD) for his support of this project. We also thank WEMD and the USGS EHP for providing funds for the acquisition of the proprietary economic dataset. We thank John Schelling, Mara Tongue (USGS Western Geographic Science Center), and Craig Weaver (Pacific Northwest Coordinator, USGS EHP) for their insightful reviews of earlier versions of the report.

\section{References Cited}

Federal Emergency Management Agency, 2001, State and local mitigation planning how-to guide No. 2-Understanding your risks: Federal Emergency Management Agency no. 386-2, last accessed August 21, 2007, at http://www.fema.gov/library/viewRecord.do?id=1880.

InfoUSA, 2010, Employer database: online dataset, last accessed December 14, 2010, at http://www.infousagov.com/employer.asp.

U.S. Census Bureau, 2009, Census 2000: Census 2000 Gateway, last accessed December 14, 2010, at http://www.census.gov/main/www/cen2000.html.

U.S. Geological Survey, 1989, The severity of an earthquake: U.S. Geological Survey General Interest Publication, $15 \mathrm{p}$.

U.S. Geological Survey, 2010, ShakeMap Archive: last accessed December 14, 2010, at http://earthquake.usgs.gov/earthquakes/shakemap/list.php?x=1\&n=global.

Wald, D., Quitoriano, V., Heaton, T., and Kanamori, H., 1999, Relationships between peak ground acceleration, peak ground velocity, and Modified Mercalli Intensity in California: Earthquake Spectra, v. 15 no. 3 , p. $557-564$.

Washington State Department of Natural Resources, 2010, Seismogenic features, Washington State Department of Natural Resources, Division of Geology and Earth Resources, last accessed January 21, 2011, at http://www.dnr.wa.gov/ResearchScience/Topics/GeosciencesData/Pages/gis_data.aspx. 